\title{
Green Eagle Nation: The Politicization of Sports Journalism in the Post- Independence Nigerian Press
}

\author{
Lynn Schler $\odot$ and Itamar Dubinsky*
}

\begin{abstract}
The sports pages of the postcolonial press provide a vantage point for viewing the tensions surrounding nation-building in Nigeria. Following independence, coverage of the Green Eagles national football team reflected aspirations for a united Nigeria, but it was also an outlet for the deep political tensions plaguing Nigeria at this time. From 1960 to 1961, contentious games against Ghanaian rivals, disputes around the choice of a national coach, and clashes with referees in international matches all enabled sports journalists to become mouthpieces for both cohesion and discord. Schler and Dubinsky demonstrate that sports pages provide opportunities for viewing the links between postcolonial sports and politics.
\end{abstract}

African Studies Review, Volume 63, Number 4 (December 2020), pp. 883-905

Lynn Schler is a Professor in African History in the Department of Politics and Government, and the Director of the Tamar Golan Africa Centre at Ben-Gurion University of the Negev. She has published books and edited volumes and articles relating to urbanization, labor history, decolonization, and nationalism in Africa. Her most recent book is Nation on Board: Becoming Nigerian at Sea (Ohio University Press, 2016). She is currently working on a history of Nigeria-Israel relations during the First Republic in Nigeria. E-mail: lynnsch@bgu.ac.il

Itamar Dubinsky is a Visiting Assistant Professor at the School of History, Philosophy, and Religion at Oregon State University. He has published articles relating to sport and development in Africa. Recent publications include "Goal Dreams: Conflicting Development Imaginaries in Ghanaian Football Academies" (with Lynn Schler) in The Journal of Modern African Studies (2019) and "Digital Diaspora: Eritrean Asylum Seekers' Cyberactivism in Israel” in African Diaspora (2020). His current research examines Ghanaian football academies through an Africapitalist prism. E-mail: Itamardu@post.bgu.ac.il

*A misspelling in one of the authors' names has been corrected since the article's original publication. See doi:10.1017/asr.2020.136.

(C) African Studies Association, 2020. This is an Open Access article, distributed under the terms of the Creative Commons Attribution license (http:/ / creativecommons.org/ licenses/by/4.0/), which permits unrestricted re-use, distribution, and reproduction in any medium, provided the original work is properly cited.

doi:10.1017/asr.2020.3 
Résumé: Les pages sportives de la presse postcoloniale offrent la possibilité d'observer et d'analyser les tensions autour de la construction de la nation au Nigeria. Après l'indépendance, la couverture de l'équipe de football nationale des Green Eagles a reflété les aspirations d'un Nigéria uni, mais elle a également représenté un exutoire pour les profondes tensions politiques qui sévissaient alors au Nigéria. De 1960 à 1961, les matchs litigieux contre des rivaux ghanéens, les disputes autour du choix d'un entraîneur national et les affrontements avec les arbitres lors de matchs internationaux, tout cela a permis aux journalistes sportifs de devenir les porte-paroles de la cohésion et de la discorde. Schler et Dubinsky démontrent que les pages sportives permettent de voir les liens entre le sport postcolonial et la politique.

Resumo: As páginas das secções desportivas da imprensa pós-colonial são um meio privilegiado para analisar as tensões que envolveram a formação do Estado-nação nigeriano. Após a independência, a cobertura da seleção nacional de futebol dos Green Eagles refletiu as aspirações em torno de uma Nigéria unida, mas foi também um veículo para expressar as profundas tensões políticas que então assolavam o país. Entre 1960 e 1961, a grande rivalidade nos jogos contra os oponentes do Gana, as polémicas em torno da escolha do selecionador nacional e os conflitos com árbitros em jogos internacionais, todos contribuíram para fazer dos jornalistas desportivos porta-vozes quer da coesão, quer da discórdia. Schler e Dubinsky demonstram que as páginas desportivas da imprensa permitem estabelecer ligações entre o desporto e a política pós-coloniais.

Keywords: Nigeria; football; nationhood; journalism; sport

"Understanding Nigeria involves understanding the print media," wrote Wale Adebanwi (2016:5). Indeed, a consensus has emerged that the press has had an outsized influence upon the history and evolution of the Nigerian polity. From its earliest inception in the colonial era, the press has played a central role in arousing nationalist sentiment and propelling the struggle for independence (Olukotun 2003; Omu 1978). As James Smoot Coleman wrote, "Newspapers and presses were the media through which the nationalistic ideas of educated Africans found an outlet; they were partly responsible for the ever-growing number of Nigerians predisposed to a nationalist ideology" (1958:186). The press thus served as "one of the most important ideological apparatuses" working for the amalgamation of national identity (Adebanwi 2016:5). Once Nigeria gained independence, the role of the press in politics became more controversial, and scholars have scrutinized the detrimental role the press has played in both generating and exacerbating political discord. Throughout the First Republic (1960-1966), Emmanuel Nwafor Mordi has argued, Nigerian newspapers abdicated their role as a watchdog of democracy and instead acted as propaganda instruments and "megaphones for feuding politicians" (2018:2059).

The Nigerian press thus embodied the unlikely coexistence between forces for unity and polarization. As Eghosa Aimufua wrote, "The press, within a multi-cultural context, can represent nationality, regional or 
sectional interests and at the same time promote a collective national identity" (2007:3). Likewise, Adebanwi's work deconstructed the contradictory role of the press as both a sower of division and a tool for fostering a collective identity. In his analysis, Nigerian newspapers "narrated to the possibilities and, at times, to the actual existence of a grand nation, of a people with a common destiny" (2016:80). Yet, each of Nigeria's "fractious ethno-nations" had its own vision of the nation, and they used their newspapers "to translate the interests and values of groups they represented into 'common' values and interests of the wider society" (2016:104). Nigerian newspapers earnestly promoted a vision of unity, but there was little commonality between the various articulations.

Historians of postcolonial Nigeria have reviewed news items, editorials, opinion pieces, and advertisements (Van den Bersselaar 2011) to understand the role the press played in fortifying a viable Nigerian identity, but little attention has been paid to the sports pages in this history. This constitutes a blind spot in our understanding of the links between print media and emergent nationhood. Beginning with independence, the sports pages at times echoed the "centrifugal tendencies" (Diamond 1988:14) that doomed political integration between Nigeria's divergent parts, but sports coverage also generated a discourse that moved from "regional thinking" (Coleman 1958:125) to one of national allegiance that was unparalleled in other sections of the newspapers or beyond. Sports journalists thus emerged as rare voices "educating the citizens about their nation" (Adebanwi 2016:11). The narratives of Nigeria that existed in the sports pages were rare expositions of "Nigerianness" that found little expression elsewhere in Nigerian society. Particularly against the backdrop of the ongoing political competition and conflict between the rival political, social, and economic interests that have continually plagued Nigeria's history, it is noteworthy that the sports pages could "whip up a sense of national pride and joy" (Aimufua 2007:283-84).

This article will examine the role that sports journalism played in nationbuilding in the early years of postcolonial Nigeria. Focusing on the first years of independence, it will examine press coverage of the Green Eagles, Nigeria's national soccer team, in some of the leading national and regional newspapers of the era. ${ }^{1}$ Between 1960 and 1961, Nigeria faced difficult challenges on the pitch and battled to defeat its staunchest rival, Ghana, while also confronting other national and professional squads from within and outside Africa. During this time, the coach of the national team was the Israeli Moshe Beit Halevi. The press coverage of the Green Eagles and their Israeli coach provides a unique vantage point for viewing the political tensions that plagued Nigeria in these years.

On the one hand, journalists and fans articulated national identification and pride for the squad, invoking an imagined Nigerian nationhood that was not reproduced outside the sports pages. In examining these narratives of nationalist fervor among Green Eagles supporters and journalists, we can gain new insights into popular aspirations that accompanied independence 
and the ways that sports rallied them. From the start of independence, football provided a means for overcoming divisions in Nigerian society.

On the other hand, criticisms of the team, its coach, and the Nigerian Football Association reveal that Green Eagle fandom was not fully insulated from the regional and ethnic tensions that shaped Nigerian history and the international politics of the era. The politicization of sports coverage led to a clear intensification of critique, demonstrating that sports journalism had the potential not only to rally new solidarities, but also to reproduce and inflame political tensions.

\section{Historicizing the Links Between Sports, the Media, and Nation-Building}

Until the 1990s, historians paid little attention to either the practice of sports or to the political, social, and cultural significance of sports in historical contexts. According to Bea Vidacs, this was because sports were largely perceived as trivial (2006:344). This perception changed when scholars increasingly identified the interconnections between sports and the political, social, and economic realms. The work of Michael Billig in particular drew attention to the links between sports, nation-building, and feelings of national belonging. Billig claimed that sports had been underappreciated as sites where "banal" nationalism "seeps into the corners of our consciousness" (1995:12). As scholars increasingly exposed the pivotal role that sports have played in shaping collective consciousness and communal identities, the emerging body of evidence confirms that "sports matters" (Dunning 1999). Histories of the modern era from across regions have revealed how sports have been exploited by both ruling classes and the masses to promote "gross displays of nationalism" (Sugden \& Bairner 1993:129). Stuart Murray and Geoffrey Allen Pigman claimed that governments leveraged sport as an "opiate of the masses" and an opportunity to demonstrate "various types of superiority, from their athletic prowess to the ideology of a particular system of state" (2014:1100). For individuals and communities, sports provide powerful outlets for expressing nationalist fervor. According to Dario Brentin and Laurence Cooley, sports arenas are "locations where symbolic representations of togetherness (e.g., national anthems, flags and emblems, fans' chants, songs, banners and uniform clothing) are displayed," and enable "the people" to identify with "the nation" (2016:7).

Historians of Africa have also examined the relationship between sports and nation-building. With regard to the colonial era, Peter Alegi argues that the establishment of black-controlled sporting clubs was an integral part of the liberation struggle (2010:36). Paul Darby claimed that sport was uniquely able to transcend tribal loyalties and "bind Africans to common social, economic and political objectives" (2013:36). From independence to the present, Michael J. Gennaro and Saheed Aderinto argue that sports continue to create bonds of national solidarity "in ways that politics cannot" and in forms "not seen in other social arenas" (2019:7). In Nigeria, Olusegun Obasa 
claimed, "sporting events connected personal identity to collective identity" (2015:13).

Within the history of sports and politics in Africa, football in particular has played a central role in arousing nationalist sentiments. Throughout the continent, Manase Kudzai Chiweshe (2019) argued, the growth of football's popularity coincided with the rise of nationalist movements. In each historical context, the links between football and nationalism took on unique forms that reflected local movements and ideologies. This can be seen in Darby's work, which discusses the links between football and the FLN in Algeria (2002:29). Darby claims that football became a symbol of Algerian resistance and prowess in the anti-colonial struggle. As Ferhat Abbas, a leading nationalist figure, proclaimed, "They [the French] rule us with guns and machines. On a man to man basis, on the field of football, we can show them who is really superior" (Darby 2002:29). The FLN formed its own football team that toured internationally, and after independence, players were rewarded with prominent government positions. Indeed, the mutually constructive relationship between nationalism and football can be identified throughout the continent. As Alegi has argued, "The game exposed newly enfranchised Africans to the gravitational pull of the idea of the nation," and football matches in stadiums became "sacred ground" for the performance of national identities (2010:55).

In examining the power of football to rally nationalist sentiment, it is crucial to acknowledge the role of the media in broadcasting and dissemination. As Marissa J. Moorman has argued, in the era of nation-building, local articulations of the nation would have had limited impact without the media to convey these ideas to a broad audience. Looking at the transmission of nationalist sentiment in Angola, she has argued that the everyday narratives of the nation that appear in Angolan music were only able to arouse broad appeal when they were transmitted on the radio (Moorman 2008). Similarly, the power of sports to drum up nationalist sentiment was inherently tied to the media outlets that reported on sporting events and news. Steven W. Pope claimed that sportswriters produce and reproduce collective consciousness, and their commentary aims "to popularize and legitimize particular philosophies, products and political ideologies" (1997:8). The nature of sports writing grants it this unique position of influence, as it "bears witness to the drama of conflict," but then captivates readers with narratives steeped in fun and adventure (Peltz-Steele 2010:6). Sports journalism can reinforce national ideals and stereotypes (Tervo 2001), but it can also revise and rethink worn-out tropes (Kioussis 2018).

To date, there has been limited academic work examining the relationship between sportswriters and nationalist sentiment in African historical contexts. Yet, some pioneering studies have laid down important theoretical and empirical foundations from which to understand these linkages. Michelle Sikes (2016) has urged historians to make more use of the sports sections in newspapers, not only for what they reveal about what happened, but also for what they can teach us about broader cultural and social currents 
shaping events. Examining coverage of women runners in Kenya, she analyzed women's experiences as athletes by deconstructing the deeper societal attitudes reflected in discourses on the sports pages. Vidacs' seminal study on the links between politics and football in Cameroon also emphasized the crucial role of the media. She argued that in the 1994 World Cup, Cameroonians broadly associated the poor showing of the national team with deeper political and economic grievances, but it was through radio call-in programs that they were able to articulate and disseminate their complaints about government, tribalism, and poor management (Vidacs 2006). Alegi's pioneering work also highlighted the links between sports journalism and nationalist sentiment in postcolonial Africa. He claimed that the press "built circulation by selling both the nationalist agenda and football coverage" (2010:56). Football fans became eager consumers of print media, and newspapers “evoked national identity and pride by denigrating the 'Other,' be that a neighboring country, controversial referee, or foreign coach" (2010:56). Sportswriters drew in audiences with the creative use of local cultural idioms, proverbs, and imagery. Sports journalists thus enabled broad connections between citizens, linking football with both national identities and longstanding traditions (Alegi 2010:57).

This study builds upon these important works to examine the links between football coverage in the Nigerian press and the broader political context of nation-building in Nigeria. The press has been credited with playing a vital role as a spearhead of nationalism in the final years of colonialism, but with regard to the tumultuous First Republic, the Nigerian press has been described as a highly partisan force (Diamond 1988:84-85), and the role the press played in forging national unity after independence has been less acknowledged. A fresh look at the sports pages can provide a new appreciation for the way newspapers continued to foster nationalist allegiances into the postcolonial era. Indeed, it is a well-worn trope to describe Nigeria as a colonial invention. From its inception, monumental efforts have been made to merge this vastly diverse amalgamation of peoples and cultures into a coherent nation. The First Republic was plagued by rivalries and competition between the Western, Eastern, and Northern regions, and political tensions continually erupted in conflict and turmoil. The conflicts of this era paved the way for the more tumultuous events that came with the first coup of 1966 and the Biafra war. Nigerian football both reflected and reproduced these tensions, while also providing unique opportunities to imagine and rally behind a unified Nigeria. A close look at the discourses surrounding football in the first years of independence can help us see not only the expression of political tensions that became so consequential, but also the ways in which Nigerians aspired to see their country. The sports pages constituted a meeting grounds where the divergent and competing expectations of independence from across Nigeria were at times shadowed by a unifying aspiration for national pride.

The study is based upon a review of football coverage in the sports sections of the West African Pilot, Daily Express, Daily Times, and the Citizen. 
Each paper for the period 6/1960-12/1962 was reviewed, although some gaps existed in the microfilms. These first few years of independence were characterized by several milestone events surrounding the national football team that can provide us with unique vantage points from which to view broader political currents. The articles in the sports pages were subjected to narrative analysis that focused on the links between football coverage and broader political agendas, ideologies, and conflicts in Nigeria. This analysis was aided by archive materials from the Israel State Archives, which provided important information regarding the coach, Moshe Beit Halevi. This analysis will affirm that historians of Nigeria have much to gain by paying closer attention to how the sports pages "both reflected and helped create African politics" (Limb 2012:16).

\section{Green Eagles and the Politics of Sports Journalism in the Emerging Nation}

Since the colonial era, football has been deeply tied to politics in Nigeria. British administrators and missionaries introduced football to inculcate the populations with broader social, cultural, and political ideas (Boer 2018:2; Onwumechili et al. 2018:404). The Nigerian nationalist elite also mobilized the political power of football, and leaders such as Nnamdi Azikiwe exploited matches for addressing crowds with an anticolonial message (Alegi 2010:40). Azikiwe was the first to use the sports pages to win support for the nationalist project. According to Alegi, the early coverage of football in the West African Pilot helped to construct a sense of "Nigerian-ness" and "absorbed football into the Nigerian anticolonial struggle" (Alegi 2010:40-41). From the start, football also revealed political cleavages. The Nigerian Football Association (NFA), founded in 1945, helped to spread the popularity of the sport; however, early on, Northerners largely rejected football for the more "dignified" sports of cricket and polo (Boer 2004:65). Competitions between ethnic nationalities, such as the Alex Oni Cup, often erupted in violence (Onwumechili et al. 2018:410). According to Ekpe Samuel Akpabot, "The winning team always saw itself as the finest tribe in the country" (1985:7). Despite these tensions, the dominance of the sport was declared by the Pilotin 1955: "Football is undoubtedly the most popular sport in Nigeria today, and hardly is there any village or hamlet throughout the country in which there is no football organization" (October 7, 1955).

With the approach of independence, football coverage increasingly engaged with questions of Nigerian identity and nationalist politics, as seen in an editorial in the Pilot in August 1960, which bemoaned the NFA's "gambling" with Nigeria's national prestige by not preparing for upcoming matches against Ghana. The editorial challenged the NFA to do a better job with Nigeria's natural talent: "If Nigeria cannot raise a strong national team from our physically fit, muscular, well-built lads of this country, the NFA better stop putting out confused teams for international matches. Each defeat of a team is a national one" (August 11, 1960). In this editorial and 
many others like it, Nigerian newspapers stoked an obsessive competition with Ghana. From 1951, Nigeria met Ghana almost on a yearly basis, resulting in a mixture of wins with some resounding defeats. For journalists and fans, each game morphed into a test of Nigeria's superiority over its main West African rival. Thus, an editorial signed by "Mr Nigeria" appeared in the Pilot prior to a game against Ghana in 1960, challenging the NFA to prove their national pride by choosing the proper line-up: "They should be patriotic enough to be proud in presenting before the outside world what is Nigeria's best. There is no other way they can do this other than to feel proud that they are citizens of this great nation" (September 7, 1960). Politicians also got involved, as seen in Prime Minister Tafewa Balewa's message to the nation prior to the match: "Once we start going we will not be beaten by any country in Africa" (Pilot, September 8, 1960). An editorial by the political party of the Eastern Region, the NCNC, voiced "grave concern" about Nigeria's lack of preparedness for international competitions: "It is a terrible slur on the integrity and reputation of Nigeria with a population of well over 35 million people that she is unable to maintain a standing team that would be able to project Nigeria's personality in international soccerdom." The party demanded that Nigeria stop picking "half-baked teams" that were a disgrace to the nation (Pilot, September 3, 1960).

The issue of coaching was a lightning rod for critique, as sportswriters and fans were generally dissatisfied with the level of coaching Nigeria had received. As one sportswriter charged following a loss to Ghana, "One fact that is retarding our progress in soccer is the absence of coaches" (Pilot, August 31, 1960). Between 1956 and 1960, Nigeria's national coach was Englishman Leslie Courtier (Eke 2018). When Courtier's term was up, The Daily Times cryptically reported that a European and an Englishman were the leading candidates for the position (May 10, 1960). The only Nigerian identified as a potential candidate was Dan Anyiam, who had coached the team for brief spells during the 1950s, but he was largely regarded as lacking enough experience (Nigerian Tribune, October 29, 1959). In the end, NFA chairman Godfrey Amachree hired the Israeli Moshe Beit Halevi to serve as the coach for the Nigerian national team. Across the continent at this time, it was commonplace for African teams to hire foreign coaches, as there was a lack of experienced indigenous coaches. This dependence on white coaches was a contentious issue at the time and continues to be to the present day (Karoney 2018). Some have condemned the ongoing reliance on European coaches as reinforcing "a continued colonial mentality that what the Europeans do is better" (Fletcher 2017:428). Vidacs has claimed that "one of the ways in which the legacy of colonialism manifests itself in Cameroonian and African football is the choice of the head coach of the national team," and listeners to call-in radio programs often condemned the employment of foreign coaches (2010:137; Nkwi \& Vidacs 1997). Hikabwa D. Chipande's work revealed that even foreign coaches with no ties to former colonial powers were rejected by football fans. In Zambia in the 1970s and 1980s, fans demanded a policy of "Zambianisation" and 
continually called for the national team to replace the Yugoslavian coach (Chipande 2018).

In Nigeria, the debates that emerged around the hiring of Beit Halevi must be understood within the complex web of ties where domestic politics overlapped with foreign relations. As it will be seen, public opinion of Beit Halevi expressed in the sports pages can not be detached from Nigeria's complex history of nation-building and competing aspirations regarding the Nigerian nation-state. Neither the press from the time nor archival documents provide a clear explanation of the choice of Beit Halevi as national coach, but it is possible to situate this decision within the broader history of ties between Israel and Nigeria in this era. From the end of the colonial era, Israel reached out to Nigeria as part of a wider effort to establish ties with the newly emerging states in Africa. This effort was aimed at offsetting Israel's diplomatic isolation resulting from the Arab-Israel conflict. Israel used the "soft power" (Nye 1990) of extensive technical and development assistance as a way of increasing its influence and strengthening relations throughout Africa. Between 1958 and 1971, tens of thousands of Africans attended courses offered by MASHAV, Israel's international aid agency, and over 2700 Israeli technical experts were sent to Nigeria to provide assistance in local projects (Peters 1992). Nigeria, because of its size and potential influence, was identified as a top priority for Israel in West Africa, and thus became one of the major recipients of Israeli aid on the continent (Ojo 1988). The Western and Eastern regions seized upon this assistance, and each established joint ventures with Israeli commercial interests to advance development schemes (Levey 2012). The Northern region, led by the Sardauna Ahmadu Bello, vehemently opposed establishing ties with Israel and instead sought strong relations with the Arab states, particularly Egypt (Akindele \& Oyediran 1986). This did not prevent the NFA chairman Godfrey Amachree from asking the Foreign Ministry of Israel to send a football coach for Nigeria's national team. The job was offered to Beit Halevi, who had coached the Israeli national team for a year and had previously led the Maccabi Tel-Aviv local team to four national championships and two national cups in the 1950s.

Beit Halevi arrived in Nigeria on September 9, 1960, just weeks before two critical matches that were highly charged with the fervor of nationalist sentiment surrounding the declaration of Nigerian Independence on October 1. On September 10, Nigeria met Ghana for a World Cup qualifying match in Lagos, a game which ended in a 2-2 draw, a result that disqualified Nigeria from the international competition. This setback was dwarfed by another game that took place on October 10 in Lagos as part of the independence celebrations. This match ended in a humiliating loss of 3-0, and the uproar that ensued in the sports pages of local newspapers was hardhitting. The scathing criticism largely focused on the NFA and the national players themselves, but also included some rebukes of Beit Halevi as the new national coach. 
Criticisms of Beit Halevi were rooted in deeper processes of nationbuilding in Nigeria and reflected the aspirations that Nigerian sports fans and sportswriters had for their new nation. Mirroring the history of Nigeria in the era, the criticism of the new coach was not unified across Nigeria, and reflected the split between the Muslim North and the Christian South regarding Middle East solidarities. For the Northern region NFA, the problem with the Israeli coach was political, but this root cause was initially veiled in the sports pages. Three days after Beit Halevi's arrival in Nigeria, the Pilot reported that Northern NFA Chairman Alhaji Danwawu came to Lagos to meet with the National Council of the Football Association: "The Northerners have come to seek a redress for an alleged grievance" (September $12,1960)$. While the grievance was not revealed, it is highly likely that dissatisfaction with the choice of an Israeli for national coach was raised. This position was made explicit following the loss to Ghana on October 10, when Danwawu publicly aired his demands that Beit Halevi be fired. As the Daily Times reported, Danwawu "criticised the appointment of an Israeli coach by the NFA and added that he was too old for the job. He said that he should be relieved of the job as soon as possible" (October 18, 1960).

For sportswriters and fans in the southern regions of Nigeria, dissatisfaction with Beit Halevi was linked to a different set of nationalist ambitions that they had invested in the national team. The team was an important symbol of the rising nation, and dominance in the realm of football was linked to aspirations for Nigerian prestige. In this regard, the rivalry with Ghana embodied hopes for Nigeria's potential and rightful place in postcolonial Africa. The humiliating loss to Ghana during independence celebrations, on Nigerian soil, engendered anger and disbelief that a country the size of Nigeria could not beat Ghana. The defeat became a call to arms, as Perry wrote in the Pilot: "The nation reacted violently to this defeat and had requested that the Nigerian Football Association must be sacked. This demand is contained in many letters now on my desk. I must at this stage join this nationwide call for the complete demolition of the NFA" (October 19, 1960). Bonar Ekanem, sportswriter at the Daily Express, was even more virulent in his critique, asking "Are we to stand again arms folded and see our team demolished by tiny Ghana?" (October 17, 1960). He attributed some of the blame to the "incompetent" NFA, and he called for the firing of Chairman Amachree. He also criticized players for lacking motivation and discipline, claiming they faked illnesses that "aroused suspicion" and spent too much time partying around Lagos (October 19, 1960). But the main target of Ekanem's dissatisfaction was the Israeli coach, who, Ekanem claimed, failed to introduce new strategies to the Nigerian game and lacked the skills needed to lead the team:

Has anyone in the NFA panel ever approached the new coach and asked him why he does not introduce an attacking technique yet? That of course depends on the language in which the question will be asked. ...The boys are a bit favoured for the English language as their lingua franca. The coach 
does not speak English. Why bring out an old coach who will find himself with language difficulty while coaching the boys? (October 19, 1960)

Fans writing to the Daily Express echoed calls to bring coaches from countries that had developed an international reputation in football. As one fan wrote, "The Government should consider soccer a national affair and try to engage at least three more coaches from the Continent. ... Our members of the NFA should hide their faces in shame until they have been able to retrieve our lost prestige" (October 12, 1960). To mirror Ghana's success, many writers believed that Nigeria needed "continental" (European) coaches, and if possible, Hungarian coaches, as Ghana had such great success under Josef Ember.

Some writers were more sympathetic to Beit Halevi. One acknowledged he had not been in Nigeria long enough to influence the team: "What a shame to our pride! What a blow to our National prestige!... We have an Israeli coach, but could it be his fault that we have not succeeded in blending a team? A team of extremes was picked and they fell in the battlefield like nine pins" (Daily Express, October 12, 1960). Another reporter from the Pilot downplayed Beit Halevi's national identity and claimed that since he was born in Poland, he in fact had continental roots. A picture of Beit Halevi had the caption: "He is a Pole, not an Israeli" (October 17, 1960). Jay Thompson, a writer for the Sunday Express, condemned the attack on Beit Halevi on political grounds:

The recent utterance of the Alhaji regarding the standard of soccer and the coach Halevi leave much to be desired. It is a tactless and most irresponsible utterance from someone in his position. I have often said that we will do more harm than good to sports if we mix it with politics. If the Alhaji would want the contract of Halevi terminated who else has he to bring forward? Or must Mr Halevi be dropped just because the Alhaji doesn't like the look of his face? It was not the fault of the coach that our boys were defeated. It is easy to lead a horse to the stream but you can't force an unwilling horse to drink from the stream. (n.d.)

Another writer, Sam Akpabot, also defended Beit Halevi, writing in the Pilot, "Before you begin blaming the new coach for the 'failure' of our team, remember that a coach can only work with the raw material that he has got...most of our players have no national pride and just cannot play football." He accused the NFA of tribalism in selecting players, and criticized the players for displaying more loyalty to their regional teams, although Akpabot admitted that he felt the same way: "Strangely enough, the thought of a Port Harcourt team playing a match excites me more than that of the National team" (October 25, 1960).

The management of the NFA pushed back against the exceedingly harsh criticism from the press, and in an editorial that appeared in the Daily Express, Assistant Secretary O.O. Oyo condemned the journalists: 
Sports writers in all the national papers have justifiably come down on the Nigerian Football Association hierarchy with a spate of criticisms and (allow me to be candid) abuse for the seemingly decadent standard of our football. ...But decency demands that criticisms need not be scurrilous and profane to be pungent. We all know the cannons of journalism-certainly personal abuse and reckless mud-slinging are not some of them. The public have a right to feel insulted by the defeat of our National soccer by a comparatively much smaller country like Ghana.... [But] the critics seem to blame every failure of our teams on the administration of the NFA without as much as pointing a finger to the unpatriotic and lifeless performances of the players. (October 20, 1960)

Correspondence from the Israeli embassy reveals that the Israeli government was alarmed by the extremely negative coverage that Beit Halevi had received in the Nigerian press. In a dispatch to the Israeli Ambassador in Lagos, the Foreign Ministry claimed that the coverage was "far from encouraging" and asked: "Are these biting criticisms of Beit-Halevi just typical for sports journalists and their regard for the Israeli coach, or does it reflect broader sentiment?" In his response, Ambassador Hanan Yavor echoed the same dismay over the unreasonable expectations that sportswriters had for the Israeli coach who had only recently arrived. As he wrote, "The current public controversy surrounding the NFA is creating a great stir and taking up more space in the newspapers than any other political issue." He feared that if Beit Halevi lost again, "he will have to pack his bags" (INA 137 2036-9-2, October 26, 1960).

Middle East politics reared its head again when the Egyptian national team was invited to play the Green Eagles at the inauguration of Azikiwe as Governor General of Nigeria. The Egyptians arrived on November 17, accompanied by the prime minister of the UAR, Kamal El-Din Hussein (Pilot, November 17, 1960). Previous matches between Egypt and Nigeria had ended with resounding Egyptian victories, and the Israeli embassy reported being extremely anxious and pessimistic about the outcome of the current game. In the end, "the Nigerians created a huge and unexpected sensation by beating the Egyptians 2:1." Yavor was full of pride for Beit Halevi's achievement, writing, "The Deputy Minister of Justice approached me after the game and said that this was not just a victory for Nigeria, but also for Israeli football!" Azikiwe hosted both teams in the evening after the game, and Yavor claimed that the Egyptians "mulled about the party in very foul moods, while Halevi was the center of attention with all the Nigerians" (INA 137 2036-9-4, November 24, 1960). Nonetheless, Halevi warned that these expressions of support were tentative: "The ball is still round, and there is no guarantee that there will not be any more unpleasant surprises" (INA 137 2036-9-, December 5, 1960).

Indeed, despite Nigeria's victory over Egypt, sportswriters were not willing to credit any win to Beit Halevi's coaching. The Pilot claimed that it was Azikiwe's presence at the game that inspired the Nigerian team to victory: 
"Evidently Nigeria's victory in this match was not without cause. The magnetic personality of the Governor-General made a remarkable contribution to the beautiful performances of the Nigerian team" (November 21, 1960). Ekanem of the Daily Express remained critical of Beit Halevi's approach, despite the victory against the Egyptians and a tie against the Moscow Dynamos a few weeks later: "After seeing the Russians, I arrived at the conclusion that faulty coaching had been responsible for the lapse in the mental alertness of our forwards" (December 3, 1960).

The season ended in mid-December, and Beit Halevi submitted his first report to the Foreign Ministry, reviewing his first three months in Nigeria (INA 137 2036-9- December 18, 1960). While he was highly satisfied with the positive relationship he had established with the team players and the NFA, he complained that the most difficult challenge he faced in Nigeria was the press, and he was struggling to work in the hostile environment:

\begin{abstract}
There is a nasty war going on here between the NFA Chairman and some sportswriters. Since he was the one who invited me here, there were already negative opinions about me before I even arrived. I have to say that these journalists stop at nothing and attack everything the NFA does, and they often demand that a European coach is hired. I also had a rocky reception from a few of the Muslims, for reasons that are quite simple and understood. One indication of just how unfair these sportswriters are is the fact that, despite the fact that I have had some big victories with the team in the last few games, not one word to my credit appeared in the pages of the newspapers afterwards. (INA 137 2036-9-צח, December $18,1960)$
\end{abstract}

Over the course of December and January, Beit Halevi tried to establish better ties with the press by conducting interviews with the Daily Express (December 22, 1960) and the Pilot (January 3, 1961). This was an acknowledgement of the power of sports journalism to influence public opinion and reflected efforts to reap the benefits of positive coverage. These efforts to endear himself to the fans and the press did not, however, immediately bear fruit. In fact, Beit Halevi's critics continued to view the Israeli coach as a symbol of second-rate football and an insult to Nigeria's national stature. Ekanem at the Daily Express complained that Ghana had coaches of "international repute," while Nigeria's coaching problems were at "the root of our failure in the international matches" (December 7, 1960). Ekanem repeatedly called for following Ghana's lead and importing a Hungarian (Daily Express, December 9, 1960). For Nigerian journalists and fans yearning to stand on equal ground with Ghana, the Israeli coach represented a compromise with inferiority.

The NFA responded to the demands of the press and the public, and the Hungarian George Vardar arrived in Nigeria in January 1961. Vardar was assigned to the national team soon after his arrival, and Beit Halevi, 
complaining that the NFA was "enchanted with the nationality" of the Hungarian, was sent to work with the police and army football teams. But this change lasted only a few weeks, according to Beit Halevi, because the players themselves preferred the Israeli coach and demanded his return (INA 137 צמת-2036-9y 2, 1961). It would thus seem that the players were not preoccupied with the same idealized view of national stature that the press and fans had invested in the Hungarian coach.

\section{Victories and New Allegiances}

The turnaround in relations between Beit Halevi and the Nigerian press came in April 1961, when the Israeli coach led the team to two draws against Ghana, the first in Lagos and the second in Accra. Although these were not wins, the previous humiliating defeats against Ghana led Nigerian fans to embrace these outcomes as resounding moral victories. Beit Halevi reported that the results were particularly impressive since the Ghanaian side had had five European coaches training the team for over two years, and yet the Nigerian players still held their own. Many spectators thought that Nigeria had outplayed Ghana in both games (INA 137 2036-9-9, May 2, 1961). Sam Akpabot at the Pilot heaped praise on the team after the first match in Lagos: "I thought that the first 45 minutes was one of the fightingest football I ever saw...I was watching Ghana for the first time since they started rubbing our noses in the mud, and I must confess I could not see how the team I watched on Saturday could have been inflicting such humiliation on the Nigerian Eleven" (April 11, 1961). Although Akpabot did not mention the national coach, much of the press coverage of Beit Halevi dramatically improved following these two games, and he was now seen as Nigeria's savior. This stark reversal in tone was evident in the Daily Times report, which called Beit Halevi "the architect of Nigeria's recovery," and heaped praised on him:

... look out for that shy-easy-going Israeli, 49-year-old Moshe Bet-Halevi and say "A big thank you!" He is a silent worker. Israel should be proud of him. We are. I have never seen a football coach in West Africa so conscientious, diligent, humble, and patient. Besides, he has the touch of humour that endeared him to the players in the Green Eagles group. If there is a duplicate it may be the Hungarian, Joseph Ember, Ghana's national coach. Where the players are, there he is in their midst. If there is hardship-he tastes of it-he ate and slept with the players even in such poor conditions like the one the team met in Freetown last month. (May 4, 1961, in INA 137 2036-9-(צח)

Beit Halevi reported on the complete reversal in tone, claiming that it was not only due to the results on the pitch, but also to the extended time he had spent with the NFA officials and sportswriters while traveling to Ghana with them. The NFA representatives from the Northern Region who had been previously hostile to him had become friends by the end of the journey. 
Even Danwawu, who had called for his sacking a few months earlier, had abandoned his antagonism toward the Israeli coach. Beit Halevi's report revealed how regional and international politics had been an undercurrent within the NFA:

These two NFA managers changed their opinion of me after 10 days of travel and became my friends. They often asked how I was doing and if I am getting my daily pocket money, and they have taken a great interest in my relationship with the boys. Of course we did not discuss politics, but we talked a lot about sports and really became friends... In a private conversation with the Chairman of the NFA Northern Region, the technical secretary asked him who was the better coach of the two national coaches. [Danwawu] replied that his opinion is just like the opinion of the players: Halevi is the better coach. And the NFA technical secretary said to him, "You in the North don't want the Israeli coach!!" to which [Danwawu] responded, "I definitely do want him, but I am just afraid of what others would say." (INA 137 2036-9-9 ", May 2, 1961)

The positive relationship with sportswriters translated into positive coverage of Beit Halevi in most of the Nigerian press from this time onward. At the Sunday Express, Babington Bakre credited Beit Halevi with working hard with the team to bring about "the new revolution" (April 30, 1961). The Sunday Post also claimed that Nigeria's success was "a credit to the coaching acumen of Moishe Beth Halevi, the mentor of the team. He more than any single individual helped in crystallising our soccer outfit from the depth of degeneration to the present near perfection" (September 3, 1961). Drum magazine published a particularly positive review of Beit Halevi's role in the team's success, describing him as a coach of "world fame," who had demonstrated his magical powers with the Green Eagles: "Forty-eight-year-old Beth Halevi from Israel is "juju-man" of our National team. He works good magic with our boys" (September 1961).

Notably, there was one Nigerian newspaper that did not embrace a new relationship with Beit Halevi after the April 1961 games against Ghana. According to Daniel Bloyce, it is important to also pay attention to what the silences of the sports pages can teach us about political and ideological currents (1997:214). The Citizen, published in the Northern Region, carried very little coverage of the Green Eagles in general, and no reports included any mention of Beit Halevi's role in the success of the team. On the day of the first match against Ghana, Citizen sportswriter Abubaker Senior downplayed previous victories: "When we sum up our soccer achievements in the last season, we shall find that we have little to be proud of" (April 8, 1961). After the tie against Ghana in Lagos, there is no full report on the game, only a small item appearing in the middle of the page, reporting "Nigeria Draws with Ghana" and announcing a rematch on April 30 in Accra (April 12, 1961). This was not exceptional, and a general review of sports coverage in the Citizen leaves the impression that there is little interest in sporting events 
centered in Lagos. Unlike Lagos-based papers, the Citizen did not portray the Green Eagles as a source of pride or national identification. Instead, the sports pages were filled with stories about cricket and football matches taking place in the North. Thus, despite the new attitude towards Beit Halevi in the southern papers and the turnaround in personal relations between Beit Halevi and Danwawu, the Citizen's lack of coverage of the national team revealed that regional tensions and geopolitics still continued to find expression in the sports pages of the press.

\section{Football and Pan-African Politics}

Perhaps no other incident gave better expression to links between national consciousness and football in the early years of independence than the games that Nigeria played against Tunisia at the end of 1961 as qualifiers for the 1962 Africa Cup games. The two games played against their North African rival exploded into a full-blown crisis entangled in Pan-African and Middle East politics. The first of the two games took place in Lagos on November 25, ending in a 2-1 victory for the Green Eagles. Ekanem, no longer a staunch critic of Beit Halevi, attributed this win to the national coach: "Beth Halevi has done his job. For the first time since his arrival in this country as a coach, I hand him a bouquet of roses. He has once said that our natural football dies hard but now he has successfully replaced it with cool-headed, disciplined and polished mid-field professional football" (Pilot, November 27, 1961). He went even further in this praise a few days later:

I must admit, I was one who had been violently impatient with his method of approach, seeing that every premier or international match in which his boys took part, there seemed to be no change. My conclusion has always been that either the Nigerian footballers are uncoachable, or the coach has no methods. When at long last I saw wonderful change for the better last Saturday, I did not hesitate to trumpet: Hail, Beit Halevi!....where we hitherto had wild and 'bushman' soccer, we have now thoroughbred and civilized exchanges with economic of energy and goal certainty. (Pilot, November 29, 1961)

The second game was held in Tunisia on December 10. Due to the hostile relations between Israel and Tunisia, Beit Halevi was not permitted by the Tunisians to come to the game, and coach Vardar went instead. There was tremendous anticipation within the sports pages of the Nigerian press as the game approached, as the winner would advance to the African Cup of Nations. One fan's letter to the Daily Times reflected a sense of what was at stake: "Everything can not be wrong in this country. There is nothing standing between us and the Africa Cup. It is only a question of doing the obvious for the good name of our country" (November 27, 1961). Three days before the game, Ekanem also reflected the nationalist sentiment of the Nigerian fans: "Their victory will delight the whole nation for, on the waves and ripples 
of the Mediterranean Sea will Nigerian victory over Tunisia be written...I have always said that I have no regard for North African or Continental football. Our boys can take care of it anywhere on the planet" (Pilot, December 7, 1961).

When the game finally came on Sunday, December 10, it quickly devolved into a fiasco that enflamed national angst and humiliation back in Nigeria. According to the Pilot report, the Green Eagles had been dominating the play after scoring early on, and were leading 2-1 until the 65th minute, when the Nigerian goalie dropped the ball and then retrieved it. The referee, an Egyptian, declared this a goal, but the linesman disputed the call. The referee then called for a free kick, and while a discussion was still going on among players on the pitch, and before a whistle was blown, a Tunisian player kicked the ball into the goal and the referee again ruled this as a goal. The Nigerians were infuriated by what they saw as the extreme bias of the Egyptian referee, and they stormed off the pitch in protest, thus losing the game and their place in the Africa Cup (Pilot, December 16, 1961). Ekanem wrote a series of impassioned articles in the Pilot on the controversial walk-off, and these articles reflected the seamless ties that linked football fandom, national identity, and postcolonial politics in post-independence sports writing:

No nation with national pride could go to play a cup match with a race of cut-
throats like the French-trained Tunisians and subject itself to indignities,
barbarous treatment, unfairly and above all the unmistakable injustice of a
referee just to keep up its own end of sportsmanship for the fun of it. The
difference is this. If the Tunisians were sportsmen, there is no reason why the
Nigerians, known for their sense of sportsmanship, a heritage in sports they
earned from their British mentors could have walked out on the Egyptian
referee and the Tunisians themselves. But the word sportsmanship is not in
their dictionaries and they could not be taught.....(T) he Nigerian team ...
have done the most noble thing to have walked out of the field with their
heads straight above their shoulders. (Pilot, December 13, 1961)

The following day, Ekanem continued to make his case for why "The walkout is proper." He charged that the Egyptian was "a wolf in a referee outfit" who conspired to help Tunisia. Left to their own devices, the Tunisians "would have been smashed to atoms." The Egyptians secured a better position for themselves in the Africa Cup with Nigeria's loss, and Ekanem charged that this was "the conspiracy between two Arab sister States to humiliate Nigeria not with studded boots but with blood-stained hands of highway robbers" (Pilot, December 14, 1961). Ekanem was also outraged that after the walk-out, the Tunisians threw the Nigerian team out of their hotel, and they reportedly wandered the streets "in the biting winter cold." Rather than face this additional humiliation, he wrote, "The Nigerians once again supplied the answer in grand style. They flew from the land of the most uncultured, most uncivilized, most stupid, most callous humanity to Rome, to take shelter in the eternal city of St. Peter" (Pilot, December 14, 1961). 
Ekanem drew a clear line between the incident and broader pan-African politics, claiming that Egypt favored Ghana over Nigeria, as both were members of the Casablanca group of states, while Nigeria was part of the Monrovia group. Pan-African politics of the era were largely shaped by the two camps and their divergent views on African unity. The Egyptian-led Casablanca group was seen as the more radical, supporting African political unity, while the Monrovia group emphasized economic cooperation as a prelude to political unification (Ismael 1968:189). Ekanem blamed "Casablanca politics" for the Egyptian referee's actions:

Nothing on earth could have made Nigeria win that match with the Casablanca prestige so thickly involved. Egypt, herself, has a score to settle with Nigeria for not recognizing her leadership in Africa. ... What took place in the Tunisian Stadium was football not played according to the written rules obeyed by all soccer nations. It was purely the Casablanca Bloc type of football that has no written rules. (Pilot, December 15, 1961)

Interestingly, the Daily Times offered another interpretation of what transpired in Tunis from English sportswriter, Keith Howard. Howard blamed the scandalous incident on the lack of uniformity among referees around the world, an issue that the English had been trying in vain to address. Referees, he argued, should display dominance without being domineering, as "the majority of British referees always seem to do." The Nigerians, he claimed, had been in contact with the British long enough and reached a "higher standard of control than in many other countries." In a veiled insult to both the Tunisians and the French, as their former colonial rulers, Howard attributed the incidents in Tunisia to the "lack of progress" the Tunisians had made in this area (December 23, 1961). Paul Dietschy (2013) has argued that colonial moral geographies such as these permeated relations between European and African national football associations and became a target of African criticisms and boycotts of FIFA from the 1960s onwards. Indeed, Howard's reflections do confirm that it was not only the Nigerians who infused their sports commentary with nationalist sentiments.

\section{Conclusion: Placing Sports Narratives in National Contexts}

The links between football and nation-building went far beyond the first two years of independence in Nigeria. As Alegi has argued, the history of football has mirrored the political, economic, and social crises that plagued the country throughout the First Republic and into the 1970s: "The country's enormous size, organizational problems, political and ethnic conflict, corruption, and a vastly inadequate infrastructure undermined Nigeria's chances for success in football as in politics" (2010:59). Likewise, Wiebe Karl Boer claimed that Nigeria's struggles for success in football were continually marred by political infighting, ethnic conflicts, and corruption-much the same as the Republic itself (2003:425). At the same time, Boer claims that 
across the tumultuous 1970s, 1980s, and 1990s, Nigeria's soccer teams have been "one of the rare arenas in which Nigeria's stature has steadily been enhanced" (2003:427). The successes of the senior teams, youth teams, and the women's team have all boosted national morale and provided Nigerians with a singular cause to support. According to Aimufua, throughout Nigeria's long history of political tensions, rivalries, and divisions, international sporting events have remained rallying points for identification with a unified nation. As he quotes journalist and politician Tony Momoh: "National integration is reflected in only one aspect of the life of our nation and that is when, for instance, Nigeria has a contest with other countries, like international football matches, international boxing, and so on ..." (Aimufua 2007:206). Citing coverage of Nigeria's 1985 triumph in the Under-17 World Cup, Aimufua claimed that the press "celebrated and flagged the Nigerian nation, thereby arousing, irrespective of ethnic, cultural and social backgrounds, a collective sense of Nigerian national identity" (2007:282).

This review of the coverage of the Green Eagles in the early years of independence indicates that Africanist scholars have much to gain by paying more attention to the sports pages as a window into the complex dynamics of postcolonial nation-building. Nigerian sports journalists have generated the kinds of narratives that are vital for forging unity among the thousands of communities brought under the nation-state of Nigeria since 1960. For Nigeria to succeed, argue Toyin Falola and Matthew M. Heaton, cultural and political discourses must "promote commonalities and downplay differences" (2008:158-59). In fact, sports journalists have been mouthpieces for both Nigerian allegiance and sectorial conflict. On the one hand, the dramatic events that shaped Nigerian football in the first two years of independence provide a vantage point from which to view the role the sports pages played in fostering an aspirational sense of Nigerianness. Yet, at the same time that coverage of the Green Eagles was infused with nationalist fervor, it also reflected the deep divisions that have plagued Nigeria. These kinds of contradictions have led renowned historian Eghosa E. Osaghae to ask, "What really is the trouble with Nigeria?" (1998:ix). In the wake of ceaseless failures, breakdowns, and conflicts that have plagued Nigeria since independence, we might ask another question: What really is keeping Nigeria together? Indeed, to begin to understand the enormous complexities of Nigeria's history, we need look no further than the sports pages of the Nigerian press.

\section{Acknowledgments}

The authors would like to thank the African Studies Program at the University of Wisconsin-Madison for help in accessing microfilms of Nigerian newspapers. We would also like to thank the staff of the National Library in Israel, who helped to locate materials and assisted with reproductions. Finally, we would like to express our deep gratitude to the anonymous reviewers and editors of the African Studies Review for providing us with extremely valuable feedback on earlier drafts of this article. 


\section{References}

Adebanwi, Wale. 2016. Nation as Grand Narrative: the Nigerian Press and the Politics of Meaning. Rochester: University of Rochester Press.

Aimufua, Eghosa. 2007. Press and National Integration: Analysis of the Role of the Nigerian Press in the Promotion of Nigerian National Identity. Ph.D. diss., Cardiff University.

Akindele, R. A., and Oye Oyediran. 1986. "Federalism and Foreign Policy in Nigeria." International Journal 41 (3): 600-25.

Akpabot, Ekpe Samuel. 1985. Football in Nigeria. London: Macmillan.

Alegi, Peter. 2010. African Soccerscapes: How a Continent Changed the World's Game. Athens: Ohio University Press.

Billig, Michael. 1995. Banal Nationalism. London: Sage.

Bloyce, Daniel. 1997. "Just Not Cricket': Baseball in England, 1874-1900." The International Journal of the History of Sport 14 (2): 207-18.

Boer, Wiebe Karl. 2003. Nation-Building Exercise: Sporting Culture and the Rise of Football in Colonial Nigeria. Ph.D diss., Yale University.

- 2004. "A Story of Heroes, of Epics: The Rise of Football in Nigeria." In Football in Africa: Conflict, Conciliation, and Community, edited by Gary Armstrong and Richard Giulianotti, 59-79. Basingstoke: Palgrave Macmillan UK.

- 2018. A story of heroes and epics: the history of football in Nigeria (1904-1960). Ibadan, Nigeria: Bookcraft.

Brentin, Dario, and Laurence Cooley. 2016. "Nationalism and sport: A review of the literature." Studies on National Movements 3: 1-33.

Chipande, Hikabwa D. 2018. "Challenge for the Ball: Elites, Fans and the Control of Football in Zambia's One-Party State, 1973-1991.” Journal of Southern African Studies 44 (6): 991-1003.

Chiweshe, Manase Kudzai. 2019. "Commercialization of football in Africa: Prospects, challenges, and experiences." In Sports in African History, Politics, and Identity Formation, edited by Michael J. Gennaro and Saheed Aderinto, 206-19. London: Routledge.

Coleman, James Smoot. 1958. Nigeria: Background to Nationalism. Berkeley: University of California Press.

Darby, Paul. 2002. Africa, Football, and FIFA: Politics, Colonialism, and Resistance. London: Frank Cass.

—. 2013. "'Let us rally around the flag': Football, nation-building, and panAfricanism in Kwame Nkrumah's Ghana." The Journal of African History 54 (2): 221-46.

Diamond, Larry. 1988. Class, Ethnicity and Democracy: The Failure of the First Republic. Syracuse: Syracuse University Press.

Dietschy, Paul. 2013. "Making football global? FIFA, Europe, and the non-European football world, 1912-74." Journal of Global History 8 (2): 279-98.

Dunning, Eric. 1999. Sport Matters: Sociological Studies of Sport, Violence and Civilization. London: Routledge.

Eke, Max. 2018. “All Super Eagles Coach: An Historical List till Date.” GoalBall. https://goalball.com.ng/super-eagles-coach.

Falola, Toyin, and Matthew M. Heaton. 2008. A History of Nigeria. Cambridge: Cambridge University Press.

Fletcher, Mark. 2017. “Confederation of African Football." In Routledge Handbook of Football Studies, edited by John Hughson, Kevin Moore, Ramón Spaaij, and Joseph Maguire, 423-33. London: Routledge. 
Gennaro, Michael J., and Saheed Aderinto. 2019. "Introduction.” In Sports in African History, Politics, and Identity Formation, edited by Michael J. Gennaro and Saheed Aderinto, 1-13. London: Routledge.

Ismael, Tareq Y. 1968. "The United Arab Republic in Africa." Canadian Journal of African Studies/La Revue canadienne des études africaines 2 (2): 175-94.

Karoney, Celestine. 2018. "Africa's solution is not in foreign coaches." https://www. bbc.com/sport/africa/44877399.

Kioussis, George N. 2018. "Remember the Teutons: English coverage of Germany at the 2010 World Cup." Soccer E Society 19 (2): 288-300.

Levey, Zach. 2012. Israel in Africa: 1956-1976. Dordrecht: Martinus Nijhoff.

Limb, Peter. 2012. "An African Newspaper in Central Johannesburg: The Journalistic and Associational Context of Abantu-Bantu." The People's Paper: A Centenary History $\mathcal{E}$ Anthology of Abantu-Batho: 298-317.

Moorman, Marissa J. 2008. Intonations: A social history of music and nation in Luanda, Angola, from 1945 to recent times. Athens, Ohio: Ohio University Press.

Mordi, Emmanuel Nwafor. 2018. "The Role of the Press in the Democratic Process: The Example of Nigeria's First Republic, 1960-1966." Pertanika Journal of Social Sciences $\mathcal{E}^{2}$ Humanities 26 (3): 2037-62.

Murray, Stuart, and Geoffrey Allen Pigman. 2014. "Mapping the relationship between international sport and diplomacy." Sport in Society 17 (9): 1098-1118.

Nkwi, Paul Nchoji, and Bea Vidacs. 1997. "Football: politics and power in Cameroon." In Entering the field: new perspectives on world football, edited by Gary Armstrong and Richard Giulianotti, 123-39. Oxford: Berg.

Nye, Joseph S. 1990. "Soft Power." Foreign Policy 80: 153-71.

Obasa, Olusegun. 2015. Sports and the modernity of leisure in Nigeria: stadium space and the symbolisms of expressions, 1930-1980. Ph.D. diss., University of Texas at Austin.

Ojo, Olusola. 1988. Africa and Israel: Relations in Perspective. Boulder, Colorado: Westview Press.

Olukotun, Ayo. 2003. "At the Barricades: Resurgent media in colonial Nigeria, 19001960." In The Foundations of Nigeria: Essays in honor of Toyin Falola, edited by Adebayo Oyebade, 229-46. Trenton: Africa World Press.

Omu, Fred I. A. 1978. Press and politics in Nigeria, 1880-1937. London: Longman.

Onwumechili, Chuka. 2001. The making of Nigeria's Super Eagles. Rome: Filippo Maria Ricci.

Onwumechili, Chuka, O. Totty, and Leelannee Malin. 2018. "Nigeria.” In The Palgrave International Handbook of Football and Politics, edited by Jean-Michel De Waele, Suzan Gibril, Ekaterina Gloriozova, and Ramón Spaaij, 403-22. Cham, Switzerland: Palgrave Macmillan.

Osaghae, Eghosa E. 1998. Crippled giant: Nigeria since independence. Bloomington: Indiana University Press.

Peltz-Steele, R.J. 2010. The Development Sportswriter: Covering African Football. University of Massachusetts School of Law.

Peters, Joel. 1992. Israel and Africa: The Problematic Friendship. London: IB Tauris.

Pope, Steven W. 1997. Patriotic Games: Sporting Traditions in the American Imagination, 1876-1926, Sports and History. New York: Oxford University Press.

Sikes, Michelle. 2016. "Print Media and the History of Women's Sport in Africa: The Kenyan Case of Barriers to International Achievement." History in Africa 43: 323-45. 
Sugden, John, and Alan Bairner. 1993. "National identity, community relations and the sporting life in Northern Ireland." In The Changing Politics of Sport, edited by Lincoln Allison, 170-205. Manchester: Manchester University Press.

Tervo, Mervi. 2001. "Nationalism, Sports and Gender in Finnish Sports Journalism in the Early Twentieth Century." Gender, Place and Culture: A Journal of Feminist Geography 8 (4): 357-73.

Van den Bersselaar, Dmitri. 2011. "Who belongs to the 'Star people'? Negotiating beer and gin advertisements in West Africa, 1949-75." The Journal of African History 52 (3): 385-408.

Vidacs, Bea. 2006. "Through the prism of sports: why should Africanists study sports?" Africa Spectrum 41 (3): 331-49.

. 2010. Visions of a better world: Football in the Cameroonian social imagination. Berlin: LIT Verlag.

\section{Archival references}

The Citizen. April 8, 1961.

- April 12, 1961.

Daily Express. October 12, 1960.

- October 17, 1960.

- October 19, 1960.

- October 20, 1960.

- December 3, 1960.

- December 7, 1960.

- December 9, 1960.

- December 22, 1960.

Daily Times. May 10, 1960.

- October 18, 1960.

—. May 4, 1961.

- November 27, 1961.

- December 23, 1961.

Drum. September 1961.

INA 137 2036-9-,צח October 26, 1960.

. November 24, 1960.
. December 5, 1960.
. December 18, 1960.
. May 2, 1961.

Nigerian Tribune. October 29, 1959

Sunday Express. April 30, 1961.

- n.d.

Sunday Post. September 3, 1961.

West African Pilot. October 7, 1955.

—. August 11, 1960.

- August 31, 1960.

- September 3, 1960.

- September 7, 1960.

- September 8, 1960.

- September 12, 1960. 
October 17, 1960.

October 19, 1960.

October 25, 1960.

November 17, 1960.

November 21, 1960.

. January 3, 1961.

April 11, 1961.

November 27, 1961.

November 29, 1961.

December 7, 1961.

December 13, 1961.

. December 14, 1961.

. December 15, 1961.

December 16, 1961.

November 27, 1963.

\section{Note}

1. During the 1940s and 1950s, Nigeria's national team was known as the "Red Devils," and its players wore scarlet jerseys. With independence, the team adopted green uniforms to match the new green and white national flag. According to Onwumechili, sports journalist Pecos of the Daily Times coined the "Green Eagles" nickname in 1961 (2001:26). Ekanem of the rival West African Pilot protested the change, claiming that green was an evil omen (November 27, 1963:7). Nonetheless, the name stuck and was upgraded to "Super Eagles" in 1988. 